\title{
An evaluation of the Life Cycle Cost of rapeseed oil as a straight vegetable oil fuel to replace petroleum diesel in agriculture
}

\author{
Grau Baquero, Bernat Esteban, Jordi-Roger ${ }^{1}$ Riba, Antoni Rius, Rita Puig \\ Escola d'Enginyeria d'Igualada, Universitat Politècnica de Catalunya. Plaça del Rei 15, \\ 08700 Igualada (Catalunya, Spain), Tel. +34 938035300, Fax +34 938031589. \\ ${ }^{1}$ Corresponding author: jordi@euetii.upc.edu
}

\begin{abstract}
The use of straight vegetable oil (SVO) as biofuel has been recognized as a valid substitute of diesel fuel in the agricultural sector under specific circumstances. Its direct use reduces most of the chemical processes involved when converting it into biodiesel, thus lowering harmful emissions. This study presents the economic analysis of a selfsupply farming model that uses rapeseed as its fuel base. This model addresses agricultural environmental concerns and can even minimize dependence on the fluctuating costs of diesel fuel. The use of SVO in agriculture can help reduce farmers' vulnerability to fossil fuel prices. The economic evaluation of the model proposed in this study shows clear economic benefits of introducing rapeseed to the traditional crop rotation of wheat and barley. The key factors analyzed in this model are diesel fuel price, diesel fuel grants and crop aids. The current situation in Spain favors the use of diesel fuel in agriculture rather than rapeseed SVO due to an 8\% profit difference. However, results show that changes in key factors slightly affect the profit margin, calculating a difference of only $3.7 \%$ for particular factor combinations. Combined environmentalfriendly agriculture supporting policies are necessary to cover this slight profit difference to promote this biofuel.
\end{abstract}

Keywords: straight vegetable oil, Brassica napus, biofuel, economic assessment, self-supply.

\section{Introduction}

The use of biofuels may help to mitigate global warming and the emission of contaminating gases [1]. However, as stated in many studies [2-6] some practices related to large-scale biofuel production may lead to higher environmental impacts than the situations they avoid such as market by-products saturation, risks associated to intensive farming production or competition with food and feed production among others.

Farming land covers approximately half of the Earth's land surface and contributed to a tenth of the world $\mathrm{CO}_{2}$ equivalent emissions in 2005. Consequently, the reduction of agricultural greenhouse gases emissions should be taken into account when analyzing the reduction of climate change [7-9].

Currently, agriculture strongly depends on fossil fuels, which leads to dependence on oil markets and generates harmful environmental emissions. Reducing this dependency and moving towards sustainability in agricultural practices needs to be a major concern for society. Sustainability includes social, environmental and economic aspects. The latter is essential to implement any new agricultural model. Due to recent price instabilities, an economic model is essential to analyze how changes in the markets affect agricultural profits. 
Life cycle costing (LCC) is a method of calculating the total cost of a product induced throughout its life cycle [10]. There are different LCC approaches depending on their target, the costs involved and the context of the LCC itself. Cost benefit analysis (CBA) is an analysis of the cost effectiveness of different alternatives in order to assess whether the benefits outweigh the costs. Thus, CBA is oriented to evaluate economic alternatives while LCC aims to cover the whole life cycle of a product. CBAbased LCC carried out in this study aims to evaluate the economic alternatives of the whole life cycle.

Life cycle assessment (LCA) has traditionally been a steady state modeling technique. In comparison, LCA-based LCC aims to also deal with quasi-dynamic modeling, taking into account changes in time by means of sensitivity analysis towards future possibility projections [11]. LCC is used in many fields, such as in building and rebuilding techniques $[12,13]$ and analysis of acquisition costs of military equipment [14]. However as a product oriented method, it is hardly used for agricultural processes.

Traditionally, economic comparisons of alternatives for any process have been mainly based on initial capital costs and the estimated income. However, operating and maintenance costs must also be examined. Externalities should be included in this case because they can greatly affect the economic feasibility of the process. LCC is an assessment that considers external factors such as compensation in the form of taxes and subsidies for example [15].

The aim of this study is to carry out an LCC-based economic evaluation of a selfsupply farming model, which focuses on minimizing environmental impacts, as well as optimizing economic benefit. This model is based on first converting to oil a portion of harvested rapeseed, which is then consumed as biofuel. The introduction of rapeseed to the crop rotation system in a Spanish Mediterranean zone to produce straight vegetable oil (SVO) for fuel on the same farm is shown in Grau et al. [16]. SVO is a biofuel obtained by pressing, filtering and degumming rapeseed without any chemical process. Nowadays its use is well known and technically available [17].

Based on LCA practice, this study analyzes the processes and policies that impact on the production, processing, use or sale of grain, seed and oil. Data was obtained from the Anoia region in Catalonia (Spain). Even though the study is centered in a Spanish region, the model parameters can be replaced with data from any other location. The proposed model does not contemplate cradle-to-grave, but cradle-to-use analysis, as the main purpose of the analysis carried out in this study is to evaluate the possible use of a field, not the fuels themselves.

The LCC-based assessment performed in this study shows the expected benefit for different farming scenarios and the analysis of the rapeseed introduction in the traditional cropping system. It also includes the possibility to use the obtained seed to produce SVO for self-consumption.

\section{Definition of the goal and scope}

\subsection{Goal definition}

The main purpose of this research is to compare the economic feasibility and limitations of self-supplied SVO as fuel in farming practices to traditional diesel-based agricultural practices through the life cycle costing (LCC) methodology [11]. The modification of a previous rotation and the economic evaluation of the fate of rapeseed (into commodity markets or used as SVO) are also addressed in this study. The objectives of this CBA-based LCC study are as follows: 
- To calculate the profit margins for different agricultural practices

- To evaluate the economic feasibility of self-supplied SVO as biofuel compared to diesel fuel

- To examine the influence of policy strategies on the practice

- To assess the future prospects of key factors affecting the economic feasibility

The selected functional unit of the system is $1.0 \mathrm{~km}^{2}$ of cultivated land.

\subsection{System boundary}

This study defines the system boundary for an agricultural practice, which includes the cropping system for each type of crop analyzed, as shown in Fig. 1. The boundaries include raw materials input, crop management (such as sowing, fertilizing, herbicide, insecticide or fungicide treatments, harvesting and seed/grain transportation) to the sale of seeds and grains. Soil no tillage technique is factored in due to its environmental and economic benefits $[18,19]$. Furthermore, the processing of the rape seed to obtain fuel (either self consumed SVO or sold to the market) is also examined.

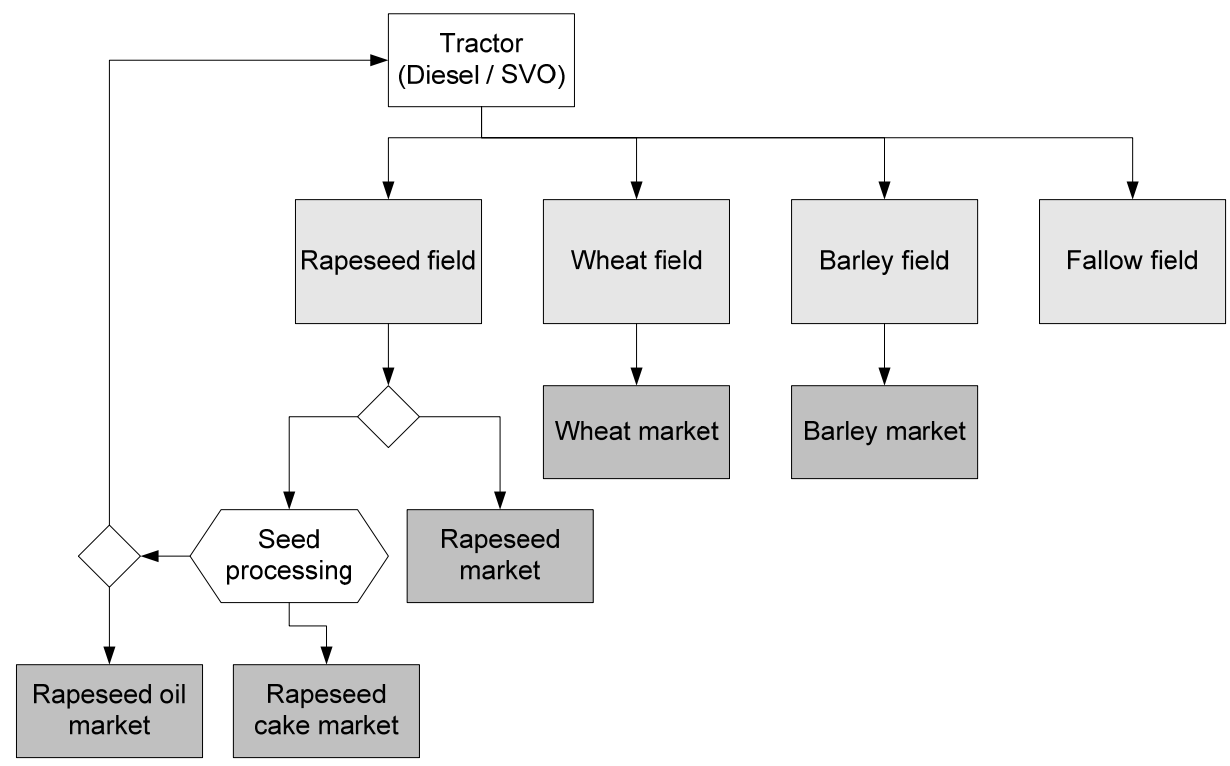

Figure 1. Cropping options scheme.

The base model taken into account here is composed by grouping three crop models, namely rapeseed, wheat, and barley. A fourth crop type -fallow- is also included. All models are based on a general field system and its particular crop type. Barley and wheat models consist on the grain production and its sale to their corresponding market. Additionally, the rapeseed model incorporates the seed processing stage to obtain the SVO, which can be used as biofuel in the agricultural practice or sold in the market.

The 6 scenarios considered according to the different possibilities of agricultural practices are shown in Table 1.

Table 1.

Considered scenarios

\begin{tabular}{lcccc}
\multicolumn{1}{c}{ Scenarios } & Rotation $^{\mathbf{a}}$ & Fuel used & Rape seed fate & Rape seed oil fate \\
\hline Diesel current & WBBB & Diesel & - & - \\
\hline Diesel classic & WBBBF & Diesel & - & - \\
\hline Diesel seed & RWBBB & Diesel & All sold to the market & - \\
\hline Diesel oil & RWBBB & Diesel & All converted into oil & Sold to the market \\
\hline
\end{tabular}




\begin{tabular}{|c|c|c|c|c|}
\hline SVO seed & RWBBB & SVO & $\begin{array}{l}\text { Some processed }{ }^{\mathrm{b}} \text { and the } \\
\text { rest sold to the market }\end{array}$ & Used as SVO \\
\hline SVO oil & RWBBB & SVO & All converted into oil & $\begin{array}{l}\text { Some used as } \mathrm{SVO}^{\mathrm{b}} \text { and } \\
\text { the rest sold to the market }\end{array}$ \\
\hline
\end{tabular}

Each scenario is obtained by the combination of different crop partitions, each one with its own conditions, as already explained. The different partitions are Barley, Barley-2 (two years after rapeseed), Fallow, Rapeseed, Wheat and Wheat-1 (one year after rapeseed).

\section{Method and data collection}

This study follows the LCC methodology taking into account all the process stages following the LCA approach and evaluating different economic alternatives like a CBA analysis. The benefit calculation is developed by modeling each crop type as well as the rapeseed processing stage. Each crop type requires its particular fertilization and crop protection products. The rapeseed processing stage is only assessed when the seed transformation into SVO is required. The use of diesel fuel or SVO in the tractor is also examined to take the consumption and the corresponding fuel emissions into account.

The model of the present study was developed using the Gabi 4 software [20]. Data on farm work, fertilizing needs and yields were obtained from the Anoia region, a dry Mediterranean area in Spain.

Crop yields, process costs and product prices are described in this section. Data related to aids and taxes affecting farmer costs and benefits are explained in section 4. Finally, the economic values introduced in the model are justified in section 5 . The results (sections 6 and 7) are calculated as the net economic benefit obtained by the farmer after processing $1.0 \mathrm{~km}^{2}$ of land taking into account different circumstances: crop rotation with or without rapeseed and using SVO or diesel as fuel.

\subsection{Field system}

The field area is considered the same for the different crops. Table 2 shows the analyzed field inputs and outputs.

Table 2

Field inputs and outputs.

\begin{tabular}{ll}
\hline \multicolumn{1}{c}{ Inputs } & \multicolumn{1}{c}{ Outputs } \\
\hline Fertilizers & Crop production \\
\hline Insecticide agent & Ammonia [Inorganic emissions to air] \\
\hline Herbicide agent & Nitrogen oxides [Inorganic emissions to air] \\
\hline Planting seed & Nitrous oxide [Inorganic emissions to air] \\
\hline Agricultural implement & Phosphorus [Inorganic emissions to fresh water] \\
\hline
\end{tabular}

By applying these inputs and outputs, the field system is analyzed when producing barley, wheat and rapeseed, with the appropriate fertilizing units and the corresponding emissions depending on the fertilizer according to IPCC 2006 method [21].

The planting seed input has an associated economic value according to the considered crop type. The agricultural implement input corresponds to working tractor hours associated to the field operations and its related costs (tractor, tractor operator and fuel). The considered tractor is fuelled either with diesel fuel or with SVO, with the corresponding consumptions and emissions for each fuel type. 


\subsection{Crop types}

The types of crop analyzed are barley, wheat and rapeseed. The first two are the most common in the studied area and are also greatly extended in Mediterranean dry areas [22, 23]. Rapeseed is also a crop option for this climate conditions even though its yield is lower than in other areas such as middle Europe wet areas.

The examined fertilization needs are shown in Table 3 and have been obtained through individually interviewing various local farmers. The collected data has been verified by technical managers of two local cooperatives [24, 25]. The fertilizing needs must be calculated according to the estimated yield of the considered field. In Table 3 reference values are given for a specific field yield.

Table 3

Fertilizing needs for barley, wheat and rapeseed crops and associated fertilizing costs (April 2010)

\begin{tabular}{lccc}
\hline & Barley & Wheat & Rapeseed \\
\cline { 2 - 4 } Basic production $\left(\mathrm{kg} \mathrm{ha}^{-1}\right)$ & 3800 & 3500 & 2300 \\
N units & 91.2 & 122.5 & 115 \\
P units & 91.2 & 87.5 & 55.2 \\
K units & 91.2 & 122.5 & 46 \\
S units & - & - & 46 \\
\hline Fertilizing costs $\left(€ \mathrm{ha}^{-1}\right)$ & 186.05 & 221.01 & 146.38 \\
\hline
\end{tabular}

To account for fertilizer prices, an appropriate combination of fertilization needs was selected, seeking minimum cost. Thus, a minimum cost algorithm was used to obtain the required amount of each fertilizer for estimated production.

Another important factor when defining a crop system is the time required for each specific agricultural job. Another important variable assessed was the fuel consumption for each field operation. These values are shown in Table 4.

Table 4

Time and fuel consumption for each crop and field operation (hours per hectare and liters per hectare).

\begin{tabular}{|c|c|c|c|c|c|c|c|c|}
\hline & \multicolumn{2}{|c|}{ Barley } & \multicolumn{2}{|c|}{ Wheat } & \multicolumn{2}{|c|}{ Rapeseed } & \multicolumn{2}{|c|}{ Fallow } \\
\hline & h ha ${ }^{-1}$ & $\mathrm{~L} \mathrm{ha}^{-1}$ & h ha ${ }^{-1}$ & $\mathrm{~L} \mathrm{ha}^{-1}$ & h ha ${ }^{-1}$ & $\mathrm{~L} \mathrm{ha}^{-1}$ & h ha ${ }^{-1}$ & $\mathrm{~L} \mathrm{ha}^{-1}$ \\
\hline Pre-emergency treatment & 0.33 & 9 & 0.33 & 9 & 0.33 & 9 & 0.67 & 18 \\
\hline Fertilizing $(\mathrm{P}, \mathrm{K}, \mathrm{S})$ & 0.50 & 7 & 0.50 & 7 & 0.50 & 7 & - & - \\
\hline Sowing (planting seed) & 0.50 & 10 & 0.50 & 10 & 0.50 & 10 & - & - \\
\hline Fertilizing (N) & 0.50 & 7 & 0.50 & 7 & 0.50 & 7 & - & - \\
\hline Herbicide treatment & 0.33 & 4 & 0.33 & 4 & 0.33 & 4 & - & - \\
\hline Harvesting & 0.92 & 20 & 0.83 & 20 & 1.25 & 25 & - & - \\
\hline Seeds transportation & 0.33 & 8 & 0.33 & 8 & 0.33 & 8 & - & - \\
\hline
\end{tabular}

Data shown in Table 4 was obtained from local farmers' experience and validated by Unió de Pagesos (local agrarian cooperative) [24]. Fuel consumption is referred to diesel fuel consumption. When the tractor is fuelled with SVO instead of diesel fuel, SVO consumption is slightly higher as explained in section 3.6.

The abovementioned crops require specific insecticide and herbicide treatment. 


\subsection{Crop Rotation}

Crop rotation systems in agriculture were developed to palliate the effect of specific crop plagues and diseases. Plagues and diseases are weakened when the crop type is changed as their intended feed is changed. This results in a natural insecticide and herbicide treatment. Classically, fallow has been used in crops to allow the soil to recover some of the nutrients lost during harvesting. Nowadays, the use of insecticides, herbicides and fertilizers decreases the need of crop rotations and the use of fallow. However, it is still very interesting to consider rotation as an agricultural practice yield enhancer that avoids the use of some pesticides when using the same amount of fertilizer $[24,25]$.

Currently, in the studied area, 4 years rotation including 1 year of wheat and 3 years of barley -WBBB rotation- is the most commonly used. The introduction of rapeseed in this rotation system brings many benefits, such as soil fluffing, plague and disease reduction; consequently increasing the next crops yield. This increase is the most interesting benefit in this economic assessment, which also gives weight to rotation. This yield increase depends mainly on weather conditions and the crop sequence. In an average year, the yield increase after rapeseed production is $10 \%$ for the following year wheat's production and 3\% for the production of barley two years after rapeseed [24, 25].

The traditional rotation in the studied area has been WBBBF, being $\mathrm{F}$ fallow. Fallow is subsidized by EU through the Common Agricultural Policy (CAP) as the other regional crops. In order to reduce or increase the production of cereals the amount of land in fallow is regulated.

\subsection{Rapeseed processing and co-products use}

Rapeseed cultivation generates different co-products, mainly rape seeds and straw. The straw obtained is returned to the field as its composition makes it a valid fertilizer, thus helping the growth of the next harvest. The rape seeds have other uses. The seeds can be directly sold to the market or can be processed to obtain oil and rape cake. The processing is done by means of a pressing plant, which is basically composed of a cold pressing stage (i.e.: screw press) followed by a filtering and a water degumming stage. The electricity consumption of processed seed is assessed at $0.55 \mathrm{MJ} \mathrm{kg}^{-1}$. This value is calculated from the electrical power consumption of a $500 \mathrm{~kg} \mathrm{~h}^{-1}$ mill according to press manufacturers (Maschinenfabrik Reinartz GmbH\&Co. KG and La Mécanique Moderne) [26, 27].

\subsection{SVO technology}

The use of SVO as fuel was firstly proposed by Rudolf Diesel in 1900, when he presented the diesel engine in Paris. There are many references in the technical literature related to the use of SVO in diesel engines [16, 28-31]. However, it is important to note that the use of SVO in unmodified diesel engines or in engines without oil preheating can lead to problems in the combustion chambers [32, 33]. Thus, in this study, a double tank system with a heat exchanger to heat the oil is taken into account. In the double tank system, some diesel fuel is used when starting and stopping the engine to avoid fuel system blockage and difficulties on the next cold start. The considered diesel fuel consumption is about 3\% of the total SVO volumetric fuel consumption according to the author's experience. In this study SVO consumption is considered $10 \%$ higher than diesel fuel, due to the different energy contents as shown in Table 5. 
Table 5

Properties of diesel fuel, unheated and heated rapeseed oil.

\begin{tabular}{|c|c|c|c|c|c|c|}
\hline \multirow[b]{2}{*}{ Fuel type } & \multicolumn{3}{|c|}{ HHV [34] } & \multicolumn{3}{|c|}{ LHV [28] } \\
\hline & $\begin{array}{c}\text { Diesel } \\
\text { fuel }\end{array}$ & $\begin{array}{c}\text { Unheated } \\
\text { rapeseed } \\
\text { oil }\end{array}$ & $\begin{array}{c}\text { Heated } \\
\text { rapeseed } \\
\text { oil }\left(70^{\circ} \mathrm{C}\right)\end{array}$ & $\begin{array}{c}\text { Diesel } \\
\text { fuel }\end{array}$ & $\begin{array}{c}\text { Unheated } \\
\text { rapeseed } \\
\text { oil }\end{array}$ & $\begin{array}{c}\text { Heated } \\
\text { rapeseed } \\
\text { oil }\left(70^{\circ} \mathrm{C}\right)\end{array}$ \\
\hline $\mathrm{HHV}\left(\mathrm{MJ} \mathrm{kg}^{-1}\right)$ & 45.23 & 39.08 & 39.08 & & & \\
\hline $\mathrm{LHV}\left(\mathrm{MJ} \mathrm{kg}^{-1}\right)$ & & & & 43.35 & 37.62 & 37.62 \\
\hline Density $\left(\mathrm{kg} \mathrm{m}^{-3}\right)$ & 0.844 & 0.918 & 0.884 & 0.815 & 0.914 & $0.884^{\mathrm{a}}$ \\
\hline Energy content $\left(\mathrm{MJ} \mathrm{dm}^{-3}\right)$ & 38.17 & 35.88 & 34.55 & 35.33 & 34.38 & 33.11 \\
\hline SVO consumption increase (\%) & & $+6.02 \%$ & $+9.50 \%$ & & $+2.68 \%$ & $+5.87 \%$ \\
\hline
\end{tabular}

${ }^{a}$ Considered equal to Nwafor study [34].

HHV: Higher heating value.

LHV: Lower heating value.

\subsection{Market prices}

The price evolution of the products factored into this study is shown in Fig. 2 [3538]. It is clear that the results of this analysis can be significantly different depending on the specific moment in time chosen to calculate them.

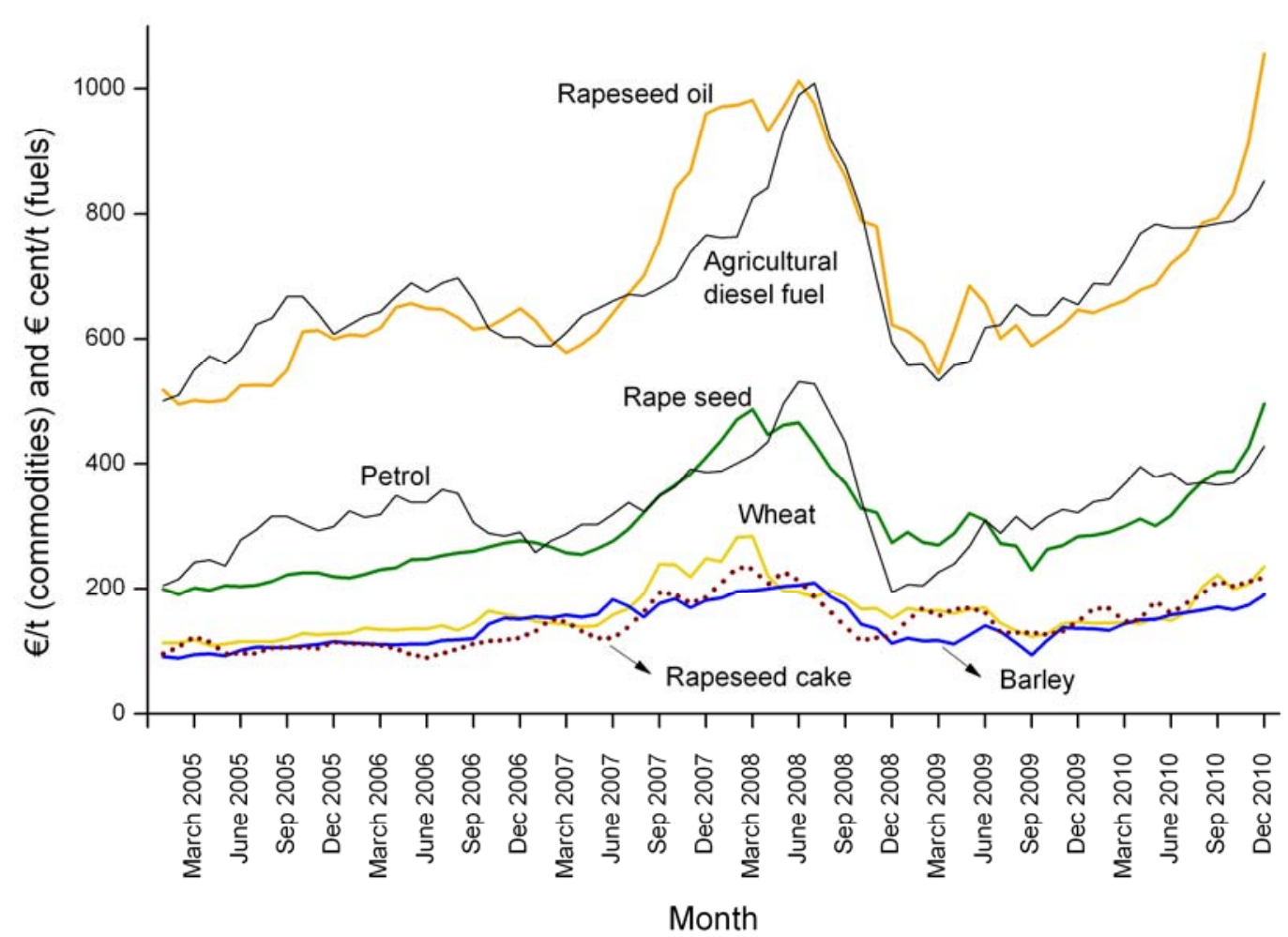

Figure 2. Market prices

The market price of seeds and grains approximately follows the evolution of petrol market price as detailed in Fig. 2.

\section{Aids and taxes}

The policies establish a regulatory framework that can account for some externalities in form of taxes and aids. Thus there is the risk of double counting the environmental effects of a system. To avoid double counting, a non-regulated market could be supposed, but the aim of this study is to obtain the real benefit of agricultural 
practices, which must include taxes and aids. Policy strategies related to crop aids, fuel aids and carbon rights market are discussed below.

The policy strategies adopted greatly affect the results of the analyzed models. Thus, the feasibility of a determined model is subjected to future regulations, which means that legislators can influence on how sustainable the agricultural practices develop.

\subsection{Crop aids}

The Common Agricultural Policy (CAP) is probably the most influencing policy on crop production patterns in the European Union (EU). From an environmental point of view, agriculture can help the mitigation of climate change by reducing dependency on fossil fuels and by diversifying energy supplies (bio-energy).

Nowadays, 2003 CAP reform is still in practice, including a mean aid to crops and fallow of about $190 €$ ha $^{-1}$ in Spain and special aid for energy crops of $45 €$ ha $^{-1}$ until its budgetary cap [39]. A new CAP reform is becoming a reality [40]. This new reform is towards green growth, which battles climate change and takes into account agricultural activity as a source of renewable energies. The 2013 CAP reform can vary the abovementioned aids, even making them disappear. Three possible policy scenarios were considered, according to the ones shown in the EU report from December 2009 [41] and its update in March 2010 [42]. Thus, a reference scenario, a conservative CAP scenario and a liberalization scenario are analyzed in section 7.3.

\subsection{Fuel taxes}

Null taxation for SVO is allowed according to EU legislation [43]. On the one hand, Spanish legislation does not specify tax levels for SVO [44, 45]. Thus, the government should tax it at the same level as petroleum diesel fuel, which SVO substitutes. Even though, SVO is considered in this study as tax free (null taxation as the other biofuels in the Spanish market).

On the other hand, diesel fuel for agricultural machinery is taxed in Spain at only $\left.0.00016 € \mathrm{~L}^{-1}[46,47]\right)$. This means that diesel fuel for agriculture is being subsidized in Spain with virtually no tax. Conversely, automotive diesel fuel is taxed with $0.307 € \mathrm{~L}^{-1}$ [48].

\section{Economic factors considered in the model}

\subsection{Installations and machinery costs}

The installations and machinery initial costs and the calculation of their assigned costs per year are shown in Table 6. Starting from an initial cost, each item is subject to inflation and worth variation leading to its end value. A linear amortization is considered when correcting the final yearly cost according to the uses given to each item. The costs ascribed to any machine are in proportion to its use on the reference area of $1 \mathrm{~km}^{2}$. Thus, one press will handle the output from $18 \mathrm{~km}^{2}$, and the cost is proportioned appropriately with a factor of $6 \%$. Accordingly, one tractor will be used for $4 \mathrm{~km}^{2}$, and with a share factor of $25 \%$.

Table 6

Installations and machinery costs.

\begin{tabular}{lccccccccc}
\hline & $\begin{array}{c}\text { Initial } \\
\text { Cost }\end{array}$ & $\begin{array}{c}\text { Infla- } \\
\text { tion }\end{array}$ & $\begin{array}{c}\text { Worth } \\
\text { variation }\end{array}$ & $\begin{array}{c}\text { End } \\
\text { value }\end{array}$ & $\begin{array}{c}\text { End } \\
\text { value }\end{array}$ & $\begin{array}{c}\text { Amorti- } \\
\text { zation }\end{array}$ & $\begin{array}{c}\text { Amorti- } \\
\text { zation } \\
\text { per year }\end{array}$ & $\begin{array}{c}\text { Share } \\
\text { factor }\end{array}$ & $\begin{array}{c}\text { Cost per } \\
\text { year }\end{array}$ \\
\cline { 2 - 10 } & $€$ & $\%$ & $\%$ & $\%$ & $€$ & years & $€$ year & $\%$ & $€$ year $^{-1}$ \\
\hline Buildings & $120000^{\text {a }}$ & $3 \%$ & $2 \%$ & $74 \%$ & 88764.04 & 30 & 1041.20 & $100 \%$ & 1041.20 \\
Installations & $40000^{\text {a }}$ & $3 \%$ & $-3 \%$ & $29 \%$ & 11604.25 & 20 & 1419.79 & $100 \%$ & 1419.79
\end{tabular}




\begin{tabular}{|c|c|c|c|c|c|c|c|c|c|}
\hline Press $1^{b}$ & 155170 & $3 \%$ & $-3 \%$ & $21 \%$ & 33037.27 & 20 & 5507.71 & $6 \%$ & 305.98 \\
\hline Press $2^{c}$ & 186850 & $3 \%$ & $-3 \%$ & $29 \%$ & 54206.35 & 20 & 6632.18 & $6 \%$ & 368.45 \\
\hline Diesel tractor & $90000^{a}$ & $3 \%$ & $0 \%$ & $58 \%$ & 52015.61 & 18 & 2110.24 & $25 \%$ & 527.56 \\
\hline SVO tractor & $95000^{a}$ & $3 \%$ & $0 \%$ & $58 \%$ & 54905.37 & 18 & 2227.48 & $25 \%$ & 556.87 \\
\hline Tractor tools & 30000 & $3 \%$ & $-3 \%$ & $29 \%$ & 8703.19 & 20 & 1064.84 & $25 \%$ & 266.21 \\
\hline
\end{tabular}

${ }^{a}$ According to data from local farmers and distributors [24, 25].

${ }^{\mathrm{b}}$ According to electronic communication with sales manager of La Mécanique Moderne [26].

${ }^{c}$ According to electronic communication with sales agent of Maschinenfabrik Reinartz [27].

Installations consumptions are considered stable and equal to $50 €$ month $^{-1}$. Taxes and building maintenance are also considered stable and equal to $150 €$ year $^{-1}$ and $200 €$ year ${ }^{-1}$ respectively according to local farmers [24, 25].

The extra cost for the storage of rapeseed is considered null, as it is supposed that the seed warehouses of the farmer besides the ones from the cooperative can cope with the amount of rapeseed that must be stored until processed into oil.

\subsection{Tractor maintenance costs}

As SVO is not volatile, the unburnt SVO fraction is diluted in the lubricating engine oil which flows down the cylinder wall into the crankcase. It makes a more frequent basic check of the tractor necessary, as shown in Table 7. A basic tractor check includes changing the engine oil and checking basic parameters. The exhaustive check is a basic check with further detailed maintenance and the replacement of filters and other components when required.

Table 7

Tractor maintenance costs ${ }^{\mathrm{a}}$.

\begin{tabular}{lccc}
\hline & Check Cost & Frequency (SVO) & Frequency (diesel) \\
\cline { 2 - 4 } & $€$ & hours & hours \\
\cline { 2 - 4 } Basic check & 150 & 250 & 500 \\
Exhaustive check & 1000 & 2000 & 2000 \\
\hline
\end{tabular}

${ }^{\mathrm{a}}$ According to data from local farmers and distributors [24, 25].

As seen in Table 7, the tractor check costs are the same for SVO and diesel-fuelled tractors, as well as the frequency measured in working hours to perform exhaustive checks. The only difference is the frequency to perform the basic check.

The yearly maintenance cost of tractor labor tools is considered at $3 \%$ of its residual value.

\subsection{European aid in the sector}

As already explained in section 4.1, CAP and energy crops aids should be analyzed. However, only the approximately $190 € \mathrm{ha}^{-1}$ aid is taken into account in the proposed model. According to the mean Spanish production of cereals excluding rice [49], the CAP aid would be at $196.25 € \mathrm{ha}^{-1}$. Consequently, an approximation of $190 € \mathrm{ha}^{-1}$ is applied and confirmed by farmers of the analyzed area [24, 25].

\subsection{Field operation materials}

The considered material costs shown in Table 8 are calculated for a conservation tillage technique, namely no-tillage practice. Conservation tillage (reduced tillage and no-tillage practices) has been proved effective to improve soil quality in Mediterranean areas as compared to traditional tillage systems [18, 22]. The fertilizing needs are adjusted to estimated productions of $3800 \mathrm{~kg} \mathrm{ha}^{-1}$ for barley, $3500 \mathrm{~kg} \mathrm{ha}^{-1}$ for wheat and 
$2300 \mathrm{~kg} \mathrm{ha}^{-1}$ for rapeseed. The values for barley and wheat are mean values obtained from local farmers [24, 25]. The rapeseed yields obtained by farmers vary from 2300 to $2800 \mathrm{~kg} \mathrm{ha}^{-1}$, and the assessed value is $2300 \mathrm{~kg} \mathrm{ha}^{-1}$ to take the lower yield margin into account.

Table 8

Field operation material costs (March 2010).

\begin{tabular}{l|c|c|c|c}
\hline & Barley & Wheat & Rapeseed & Fallow \\
\cline { 2 - 5 } & $€$ ha $^{-1}$ & $€$ ha $^{-1}$ & $€$ ha $^{-1}$ & \\
\cline { 2 - 5 } Insecticide treatment & 11.25 & 11.25 & 11.25 & - \\
Herbicide treatment & 63 & 83 & $103^{\mathrm{a}}$ & 6 \\
Fungicide treatment $^{\mathrm{b}}$ & 7.5 & 7.5 & - & - \\
Fertilizing (N, P, K, S) $^{\text {Sowing (planting seed) }}$ & 186.05 & 221.01 & 146.38 & - \\
\hline
\end{tabular}

${ }^{\mathrm{a}}$ Reduced value as it is only needed a mean of 4 out of 5 years in the considered region (the cost for 1 application would be of $128 € \mathrm{ha}^{-1}$ ).

${ }^{\mathrm{b}}$ Only applies to cereals and is only needed 2 out of 5 years due to the considered region (the cost for 1 application would be of $18.75 € \mathrm{ha}^{-1}$ ).

The fertilizing costs shown in Table 8 are for a specific timeframe (March 2010). These costs are subjected to the fluctuations of international market prices. However, these fluctuations have a minimum effect on a comparative results analysis.

\subsection{Fuel and labor costs}

Fuel costs are assessed as being equal to the market prices, also taking into account that diesel fuel in Spain is subsidized with approximate tax value.

Labor costs are assessed at $18.83 € \mathrm{~h}^{-1}$, which takes into account a $25000 €$ annual gross salary, a 35\% for social security and the corresponding working days, holidays and vacations. This value is very close to the 2009 and 2010 mean hourly labor costs in the Spanish industry [38].

\subsection{Analyzed market prices}

As market prices vary considerably over time and greatly affect the results, the 2010 year's mean values have been selected (see Table 9).

Table 9

Economic mean values for 2010 period.

\begin{tabular}{|c|c|c|c|c|c|c|c|}
\hline & Wheat & Barley & $\begin{array}{l}\text { Rape } \\
\text { seed }\end{array}$ & $\begin{array}{l}\text { Rape } \\
\text { oil }\end{array}$ & $\begin{array}{l}\text { Rape } \\
\text { cake }\end{array}$ & $\begin{array}{l}\text { Diesel fuel } \\
\text { with taxes }\end{array}$ & $\begin{array}{c}\text { Granted } \\
\text { agricultural } \\
\text { diesel fuel }\end{array}$ \\
\hline & $€ \mathrm{Mg}^{-1}$ & $€ \mathrm{Mg}^{-1}$ & $€ \mathrm{Mg}^{-1}$ & $€ \mathrm{Mg}^{-1}$ & $€ \mathrm{Mg}^{-1}$ & $€ \mathrm{~L}^{-1}$ & $€ \mathrm{~L}^{-1}$ \\
\hline Year 2010 & 170.87 & 156.06 & 330.05 & 719.37 & 176.34 & 1,061 & 0,754 \\
\hline
\end{tabular}

These values are used to calculate the different scenarios and are taken as a basis for the time-evolution analysis in section 7.4.

\section{Results}

The results in this section are calculated by means of a cost-benefit analysis (CBA). Costs include investments which have been linearly distributed among the years of use, as this study aims to calculate a mean yearly economic benefit of the farming practice (a complete season). The benefit is shown as a representative parameter of the viability of each possible scenario as seen in Fig. 3, which also shows the contribution of each crop to the profit margin. 


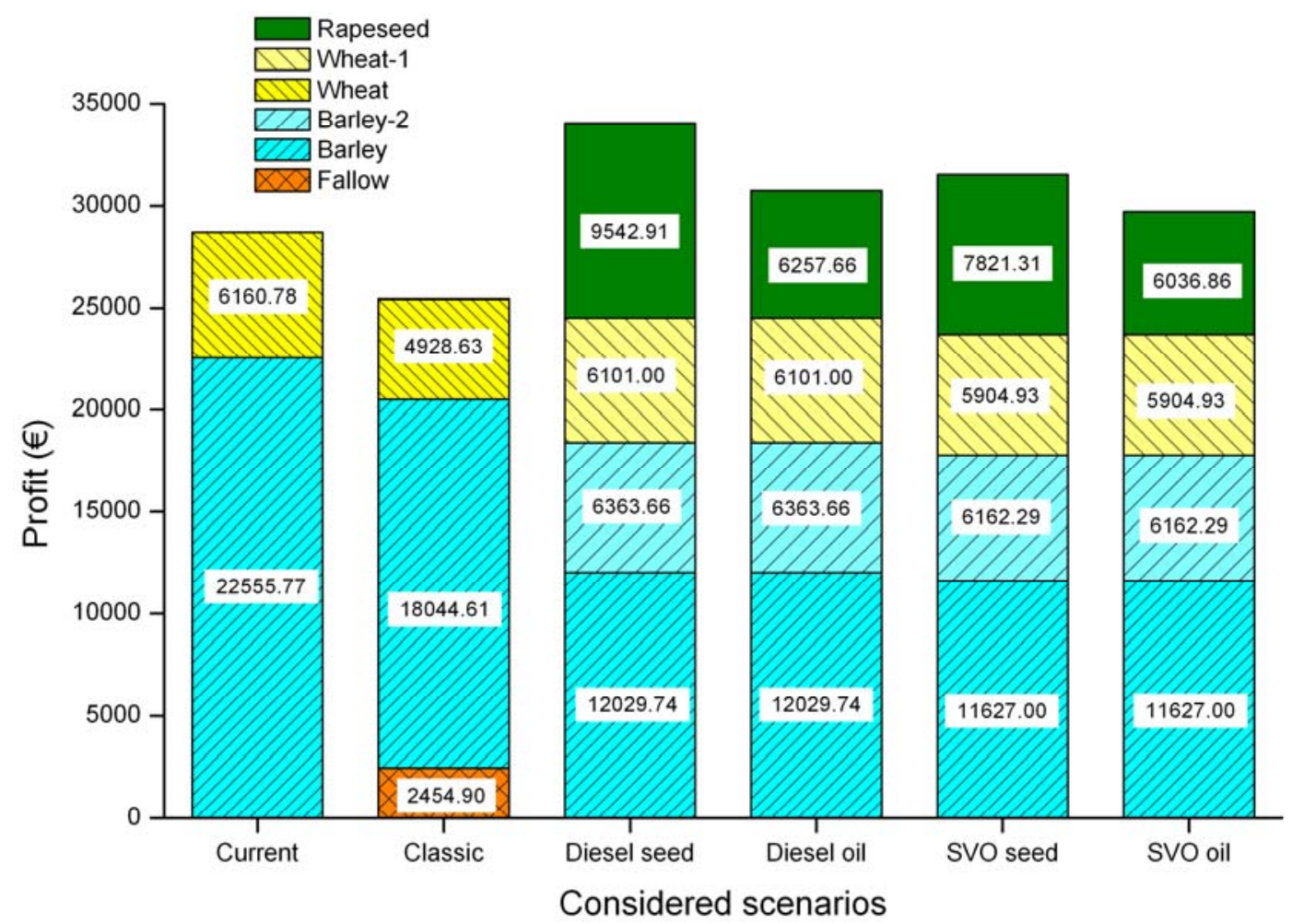

Figure 3. Economic benefits for 2010 conditions and crop contribution.

It is clear that for current economic conditions, applying crop rotation RWBBB with diesel fuel use (diesel seed scenario) is the best option. The SVO seed scenario is very close to this good option, which uses the same rotation scheme but destines part of the harvested seed to produce SVO as fuel for the farming machinery. The later reduces the amount of diesel used in the agricultural practice.

Crops contributions to profits are higher or lower according the proportion of each crop partition. Even not having production, fallow still has profit margin due to the CAP aid. Rapeseed when not processed gives a higher cost benefit per land unit than the other analyzed crop types. It is clear from the results that small-scale processing of rapeseed to sell oil is not economically feasible.

The scenarios results show a clear profit increase in diesel seed and SVO seed scenarios comparing to the current scenario (18\% and $10 \%$ profit increase, respectively). Thus these scenarios as well as the current scenario are the ones used for comparisons in the following sections.

\section{Effects of policy regulations on end results}

In the following subsections, an evaluation taking into account the results of policy regulations on the economic model is performed. A sensitivity analysis was carried out to evaluate the profit differences depending on changes over time for different parameters. Price projections were also factored in, constituting a quasi-dynamic model analysis to complete the LCC results with the profit variation expected over time. Some parameters are evaluated to show the changes that can make SVO seed scenario as profitable as using diesel seed.

The analyses carried out in this section are grouped into diesel fuel tax scheme analysis, CAP reform scenarios and time-projection analysis. 
7.2 Diesel fuel tax sensitivity analysis

Taking into account diesel fuel grant distribution in Spain, diesel fuel prices for agriculture is lower than the diesel fuel market price (the diesel fuel market price is about 1.5 times higher, 1.507 in 2009 and 1.407 in 2010).

Diesel fuel in Spain is generally taxed at $0.307 € \mathrm{~L}^{-1}$. However, agricultural diesel fuel is only taxed at $0.07871 € \mathrm{~L}^{-1}$. Moreover, the current tax scenario for diesel fuel in Spain offers agricultural grants for machinery at a refund rate of $99.8 \%$ of the current agricultural diesel fuel tax. This situation heavily influences diesel fuel use in agriculture. Thus a comparison is performed between 3 different options:

- Current taxation: agricultural diesel fuel taxed at $0.00016 € \mathrm{~L}^{-1}$.

- Agricultural taxation: agricultural diesel fuel taxed at $0.07871 € \mathrm{~L}^{-1}$.

- Diesel fuel generic taxation: agricultural diesel fuel taxed as generic diesel fuel at $0.307 € \mathrm{~L}^{-1}$.

From Fig. 4, it is clear that the scenarios using only diesel fuel are more influenced by diesel fuel tax variation than the SVO-seed scenarios. This tax variation leads to a change in benefit difference between diesel seed and SVO seed scenarios from $8.0 \%$ (current taxation) to 3.7\% (diesel generic taxation). Despite the fact that SVO based model is more stable, it is interesting to point out that the SVO option would be economically feasible in Spain if the policies supported the use of this biofuel in agriculture in the same way as with diesel fuel.

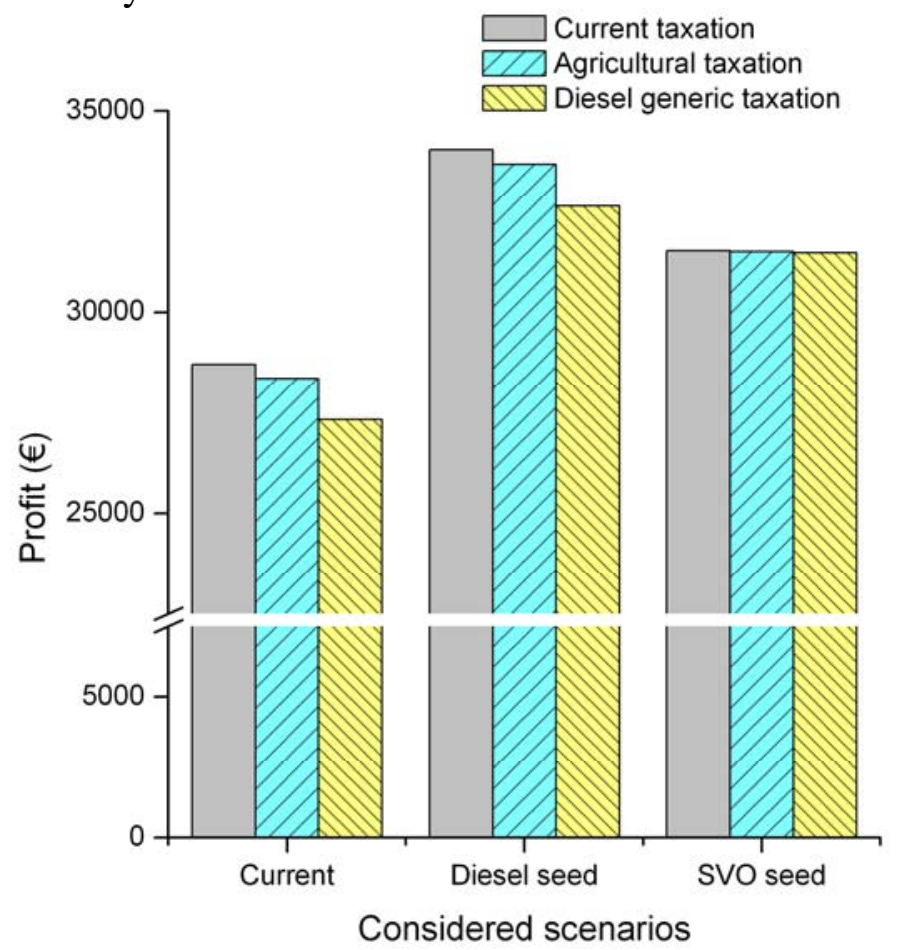

Figure 4. Profit versus diesel fuel tax variation.

It should be also discussed whether the aids to agriculture should support fossil fuels or biofuels. In the latter case, the benefit for the farmer would be almost the same, and also allows farmers to gain independence from diesel fuel price fluctuation.

The economic feasibility of SVO vs. diesel fuel would be achieved if the diesel tax grants were $137 \%$ higher $\left(0.726 € \mathrm{~L}^{-1}\right.$ instead of the current $\left.0.307 € \mathrm{~L}^{-1}\right)$, which at present is a highly unrealistic measure. 


\subsection{CAP reform scenarios}

A study from the EU shows 3 possible tax scenarios for the CAP reform [42], a conservative, a reference and a liberalization CAP. These three options reduce the current CAP aid of approximately $190 € \mathrm{ha}^{-1}$ to $161.5 € \mathrm{ha}^{-1}, 133 € \mathrm{ha}^{-1}$ and $0 € \mathrm{ha}^{-1}$, respectively. As the income from CAP is proportional to the hectares of land, the profit reduced is the same for all the scenarios.

It is thus clear that taking only economic results into account, a CAP reduction strongly affects farmers' profits. The situation of a null CAP aid would clearly lead to a price increase of agricultural products or an unsustainable decrease in farmer's incomes.

\subsection{Time-projection analysis}

Based on the LCC methodology, the time-projection analysis assessment is used here to calculate the profits for future conditions through today's Euros. The aim of this section is not to model real diesel fuel future prices, and therefore uses instead an approach to diesel fuel's possible evolution.

In this study, the costs of grains and seeds are assumed to be directly related to diesel fuel price to model its dependency. Machinery, installations, herbicides and fungicides are considered constant due to their low significance in the global profits. On the other hand, labor costs, fertilizers prices and diesel fuel price projections are supposed to increase linearly. Thus, taking into account the price changes over the last decade, linear increases have been selected to estimate projected prices. Diesel fuel dedicated to agriculture is considered to increase $2.13 \%$ per year, labor costs for the Spanish industry at a $1.24 \%$ increase and fertilizer prices at a $2 \%$ increase. Carbon market allowances are considered to increase $2.5 \%$ annually, as stated in section 4.3 [50]. The price changes of harvested products are calculated taking into account their link with diesel fuel for the last 5 years. Thus, their future estimated price depends on each base price and each diesel fuel price analyzed per year.

Results in Figure 5, show that the use of diesel fuel remains to be profitable compared to self-supplied SVO. However, the difference between Diesel seed and SVO seed scenarios remains close, varying from $4.57 \%$ in 2010 to $3.42 \%$ in for 2050 price calculations. Thus, the projected analysis shows that even obtaining a slight difference between the scenarios, the tendency remains the same. 


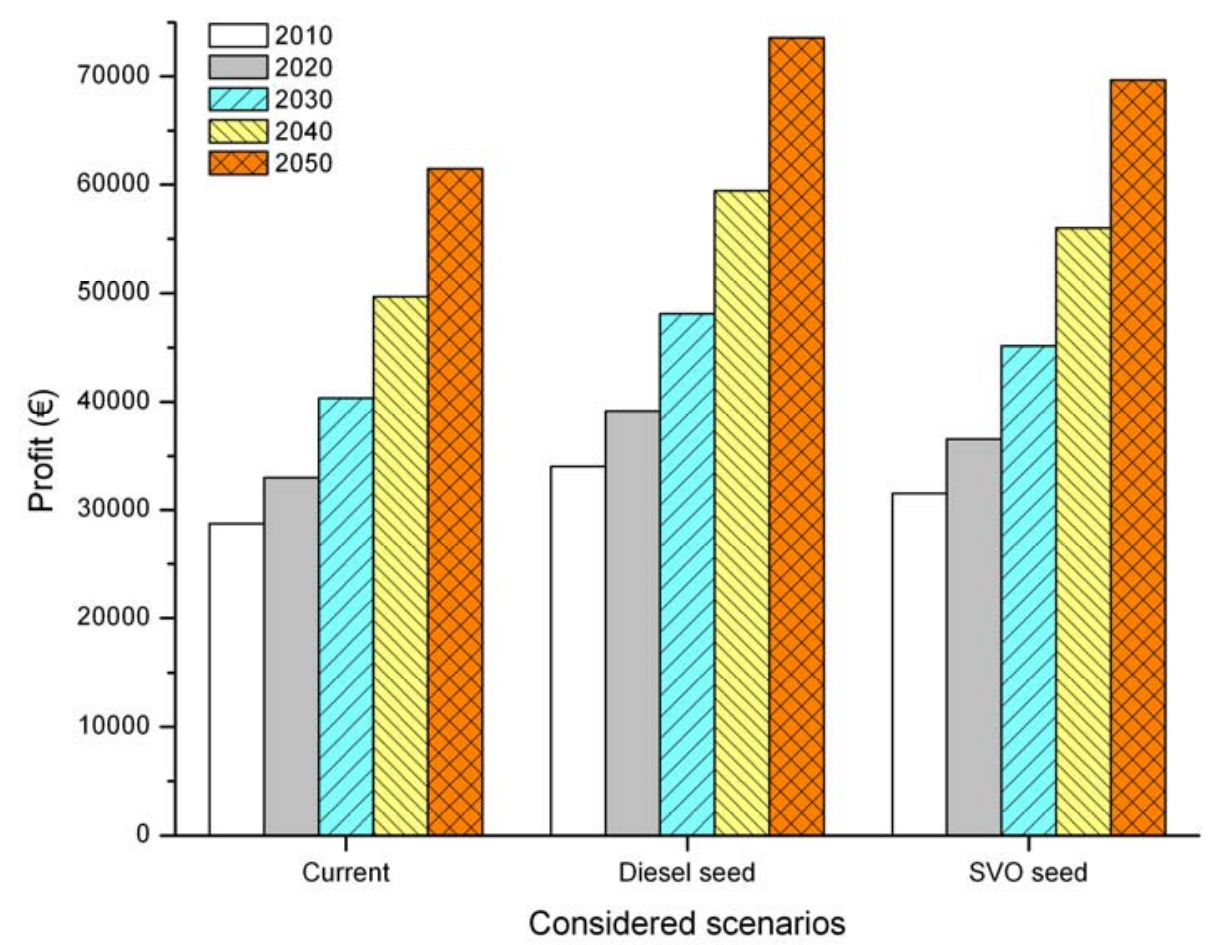

Figure 5. Crops profit time-projection analysis (2010-2050).

When taking into account $\mathrm{CO}_{2}$ emission rights costs, results keep the same tendency. In this case the benefit for Diesel seed scenario against SVO oil scenario would be from $\sim 4.5 \%$ in 2010 to $3.3 \%$ in 2050. The benefits get closer, but with no final changes when comparing the tendencies.

\section{Conclusions}

In this study a comparative economic assessment of six agricultural scenarios including a rapeseed-based self-supplied fuel farming model has been carried out. The use of self-supplied SVO in farming can help to reduce the dependency on fuel price flux, giving independence to the farmer. Additionally, SVO fuel production and self consumption reduces GHG emissions with no major profit reduction to farmers' incomes. The profit decrease calculates at only $8 \%$.

The comparative economic assessment includes a diesel fuel tax sensitivity analysis (a CAP reform analysis and also a price-projection analysis.

Results of these analyses show that Spanish diesel fuel farming grants do not promote SVO to be introduced as fuel for agricultural practices. Furthermore, when analyzing unsubsidized diesel fuel, the profit margin is still higher than SVO-based methods calculated at 3.7\%. The CAP affects profits for common diesel fuel and biofuels equally. Consequently, if the fore coming CAP reform only introduces aids reduction, it would only decrease farmers' benefits without enhancing the use of more sustainable options. Current policies do not specifically support self-supply fuels in the farming industry; therefore SVO is unable to compete with established diesel fuel agriculture practices. In the time-projection analysis carried out, results show a minor reduction in profits between diesel seed and SVO seed scenarios over time. Calculations show that slight isolated changes in key factors do not have much impact on profits and depending on the type of crop management used, the final cost benefit difference could be nearly the same for both SVO and diesel fuel based scenarios.

The implementation of local fuel generation models leads to a win-win situation for farmers and society. On one hand, farmers are less dependent on diesel fuel and on the 
other; society gets a reduction in emissions and a decrease of long distance fuel transport. Nevertheless, there is no expected profit increase in the current situation without changes in key issues such as energy and environmental policies.

\section{References}

[1] IPCC. Climate Change 2007: Synthesis Report. Summary for Policymakers. Section 4. In: Pachauri RKaR, A., editor. Contribution of Working Groups I, II and III to the Fourth Assessment Report of the Intergovernmental Panel on Climate Change. Geneva, Switzerland: Intergovernmental Panel on Climate Change; 2007, p. 104.

[2] von Blottnitz H, Curran MA. A review of assessments conducted on bio-ethanol as a transportation fuel from a net energy, greenhouse gas, and environmental life cycle perspective. J Clean Prod 2007; 15(7):607-19.

[3] Goldemberg J, Guardabassi P. Are biofuels a feasible option? Energy Policy 2009; 37(1):10-14.

[4] Bindraban PS, Bulte EH, Conijn SG. Can large-scale biofuels production be sustainable by 2020? Agric Syst 2009; 101(3):197-99.

[5] Reijnders L, Huijbregts MAJ. Biogenic greenhouse gas emissions linked to the life cycles of biodiesel derived from European rapeseed and Brazilian soybeans. J Clean Prod 2008; 16(18):1943-48.

[6] Taheripour F, Hertel TW, Tyner WE, Beckman JF, Birur DK. Biofuels and their by-products: Global economic and environmental implications. Biomass Bioenerg 2010; 34(3):278-89.

[7] Fischer G, Prieler S, van Velthuizen H, Lensink SM, Londo M, de Wit M. Biofuel production potentials in Europe: Sustainable use of cultivated land and pastures. Part I: Land productivity potentials. Biomass Bioenerg 2010; 34(2):159-72.

[8] IPCC. Climate Change 2007: Mitigation of Climate Change. Chapter 8: Agriculture. In: B. Metz ORD, P.R. Bosch, R. Dave, L.A. Meyer, editor. Contribution of Working Groups I, II and III to the Fourth Assessment Report of the Intergovernmental Panel on Climate Change. Cambridge University Press, Cambridge, United Kingdom and New York, NY, USA.: Intergovernmental Panel on Climate Change; 2007, p. 851.

[9] Zekic V, Rodic V, Jovanovic M. Potentials and economic viability of small grain residue use as a source of energy in Serbia. Biomass Bioenerg 2010; 34(12):1789-95.

[10] Lee JY, Yoo M, Cha K, Lim TW, Hur T. Life cycle cost analysis to examine the economical feasibility of hydrogen as an alternative fuel. Int J Hydrog Energy 2009; 34(10):4243-55.

[11] Hunkeler D, Lichtenvort K, Rebitzer G. Environmental Life Cycle Costing. In: Gorsuch JW, editor. New York: Society of Environmental Toxicology and Chemistry (SETAC); 2008.

[12] Ouyang JL, Ge J, Hokao K. Economic analysis of energy-saving renovation measures for urban existing residential buildings in China based on thermal simulation and site investigation. Energy Policy 2009; 37(1):140-49.

[13] Nassen J, Sprei F, Holmberg J. Stagnating energy efficiency in the Swedish building sector-Economic and organisational explanations. Energy Policy 2008; 36(10):3814-22.

[14] Huppes G, Rooijen Mv, Kleijn R, Heijungs R, Koning Ad, Oers Lv. Life Cycle Costing and the Environment. Report of a project commissioned by the Ministry of VROM-DGM for the RIVM Expertise Centre LCA. In: LCA REC, editor: Ministry of VROM-DGM; 2004, p. 52. 
[15] Rebitzer G, Hunkeler D. Life cycle costing in LCM: Ambitions, opportunities, and limitations - Discussing a framework. Int J Life Cycle Assess 2003; 8(5):253-56.

[16] Grau B, Bernat E, Antoni R, Jordi-Roger R, Rita P. Small-scale production of straight vegetable oil from rapeseed and its use as biofuel in the Spanish territory. Energy Policy 2010; 38(1):189-96.

[17] Hossain AK, Davies PA. Plant oils as fuels for compression ignition engines: A technical review and life-cycle analysis. Renew Energy 2010; 35(1):1-13.

[18] Melero S, Lopez-Garrido R, Murillo JM, Moreno F. Conservation tillage: Shortand long-term effects on soil carbon fractions and enzymatic activities under Mediterranean conditions. Soil Tillage Res 2009; 104(2):292-98.

[19] Alvaro-Fuentes J, Lopez MV, Arrue JL, Moret D, Paustian K. Tillage and cropping effects on soil organic carbon in Mediterranean semiarid agroecosystems: Testing the Century model. Agric Ecosyst Environ 2009; 134(3-4):211-17.

[20] PE_International. GaBi 4. In: GMBH PE, editor. Institut für Kunststoffprüfung und Kunststoffkunde. Stuttgart, Echterdingen; 2010.

[21] IPCC. Guidelines for National Greenhouse Gas Inventories, prepared by the National Greenhouse Gas Inventories Programme. In: Eggleston HS, Buendia, L., Miwa, K., Ngara, T. and Tanabe, K., editor. Volume 4 Chapter 11, N2O emissions from managed soils, and CO2 emissions from lime and urea application. IGES, Hayama, Japan: Intergovernmental Panel on Climate Change; 2006.

[22] Madejon E, Murillo JM, Moreno F, Lopez MV, Arrue JL, Alvaro-Fuentes J, et al. Effect of long-term conservation tillage on soil biochemical properties in Mediterranean Spanish areas. Soil Tillage Res 2009; 105(1):55-62.

[23] Alvaro-Fuentes J, Lampurlanes J, Cantero-Martinez C. Alternative Crop Rotations under Mediterranean No-Tillage Conditions: Biomass, Grain Yield, and Water-Use Efficiency. Agron J 2009; 101(5):1227-33.

[24] Vidal J. Local farmer and coordinator of Unió de Pagesos Anoia (local cooperative). Igualada (Barcelona); 2010.

[25] Berenguer S. Local farmer and responsible of the agrarian cooperative of Sta. Coloma de Queralt. Sta. Coloma de Queralt (Tarragona); 2010.

[26] Bosquet A. Electronic communication with sales manager of La Mécanique Moderne. 2009.

[27] Braack F. Electronic communication with sales agent of Maschinenfabrik Reinartz GmbH\&Co. KG.; 2009.

[28] Altin R, Cetinkaya S, Yucesu HS. The potential of using vegetable oil fuels as fuel for diesel engines. Energy Conv Manag 2001; 42(5):529-38.

[29] Esteban B, Baquero G, Puig R, Riba J-R, Rius A. Is it environmentally advantageous to use vegetable oil directly as biofuel instead of converting it to biodiesel? Biomass Bioenerg 2011; 35(3):1317-28.

[30] He Y, Bao YD. Study on rapeseed oil as alternative fuel for a single-cylinder diesel engine. Renew Energy 2003; 28(9):1447-53.

[31] Thuneke K, Emberger P. Exhaust gas emission characteristics of rapeseed oil fuelled tractors - Investigations at a test stand. Conference: Agricultural Engineering 2007; 2007, p. 47-52.

[32] Labeckas G, Slavinskas S. Comparative performance of direct injection diesel engine operating on ethanol, petrol and rapeseed oil blends. Energy Conv Manag 2009; 50(3):792-801.

[33] Labeckas G, Slavinskas S. Performance of direct-injection off-road diesel engine on rapeseed oil. Renew Energy 2006; 31(6):849-63. 
[34] Nwafor OMI. Emission characteristics of diesel engine running on vegetable oil with elevated fuel inlet temperature. Biomass Bioenerg 2004; 27(5):507-11.

[35] European_Central_Bank, Euro foreign exchange reference rates, www.ecb.int/stats/exchange/eurofxref/html/index.en.html (2004-2010), accessed: 2011.

[36] FAO, Reports on international commodity prices, www.fao.org/es/esc/prices/WeeklyPricesServlet.jsp (2004-2010), accessed: 2011.

[37] Indexmundi, Commodity prices (source: International Monetary Fund), www.indexmundi.com (2004-2010), accessed: 2010.

[38] MITYC, Spanish Ministry of Industry, Comerce and Tourism. Monthly fuel reports,

www.mityc.es/energia/petroleo/Precios/Informes/InformesMensuales/Paginas/IndexInf ormesMensuales.aspx (2004-2010), accessed: 2010.

[39] Regulation_1782/2003/EC. Council Regulation 1782/2003/EC establishing common rules for direct support schemes under the common agricultural policy and establishing certain support schemes for farmers. 2003.

[40] CioloS D, The future of European agricultural policy - Call for a public debate, Speech to the European Parliament's Agriculture Committee Brussels, 12 April 2010., http://europa.eu/rapid/pressReleasesAction.do?reference=SPEECH/10/150\&format=HT ML\&aged=0\&language $=E N \&$ guiLanguage $=$ en (2010), accessed: 2010 .

[41] European_Commission. Prospects for agricultural markets and income in the European Union 2008-2015. Brussels: European Comission. Directorate-General for Agriculture and Rural Development.; 2009, p. 37.

[42] Nowicki P, Goba V, Knierim A, Meijl Hv, Banse M, Delbaere B, et al. Scenar 2020-II - Update of Analysis of Prospects in the Scenar 2020 Study

- Contract No. 30-CE-0200286/00-21. In: Uden Gv, editor. Brussels: European Commission, Directorate-General

Agriculture and Rural Development; 2009, p. 205.

[43] Directive_2003-30-EC. Directive of the European Parliament and of the Council on the promotion of the use of biofuels or other renewable fuels for transport. Official Journal of the European Union L123; 2003, p. 42-46.

[44] Spanish_law_22/2005. Spanish law 22/2005 of 18th November, 2005, por la que se incorporan al ordenamiento jurídico español diversas directivas comunitarias en materia de fiscalidad de productos energéticos y electricidad y del régimen fiscal común aplicable a las sociedades matrices y filiales de estados miembros diferentes, y se regula el régimen fiscal de las aportaciones transfronterizas a fondos de pensiones en el ámbito de la Unión Europea. BOE 2005; 277(19th November 2005):37821- 38.

[45] Directive_2003/96/EC. Directive 2003/96/EC of the European Parliament and of the Council restructuring the Community framework for the taxation of energy products and electricity. Official Journal of the European Union; 2003, p. 51-70.

[46] Spanish_law_38/1992. Ley 38/1992, de 28 de diciembre, de Impuestos Especiales. BOE 1992; 312(29th December 1992):44305-31.

[47] Spanish_law_26/2009. Ley 26/2009, de 23 de diciembre, de Presupuestos Generales del Estado para el año 2010. BOE 2009; 309(24th December 2009):1088049227.

[48] Spanish_law_8/2009. Real Decreto-ley 8/2009, de 12 de junio, por el que se conceden créditos extraordinarios y suplementos de crédito, por importe total de 19.821,28 millones de euros, y se modifican determinados preceptos de la Ley 38/1992, de 28 de diciembre, de Impuestos Especiales. BOE 2009; 143(13th June 2009):49890902. 
[49] European_Union, Agriculture in the European Union: statistical and economic information, http://ec.europa.eu/agriculture/agrista/2009/table_en/index.htm (2009), accessed: 2010.

[50] Wise M, Kyle GP, Dooley JJ, Kim SH. The impact of electric passenger transport technology under an economy-wide climate policy in the United States: Carbon dioxide emissions, coal use, and carbon dioxide capture and storage. Int $\mathrm{J}$ Greenh Gas Control 2010; 4(2):301-08. 